\title{
Uji Kadar Hara Nitrogen, Fosfor, dan Kalium pada Kompos Pelepah Kelapa Sawit dengan Pemberian Trichoderma harzianum dan Kotoran Sapi
}

\section{(Study of Nitrogen, Phosphorus, and Potassium Nutrients Content in the Compost of Oil Palm Fronds with the Application of Trichoderma harzianum and Cow Dung)}

\author{
Sakiah $^{1)^{*}}$, Muhammad Yusuf Dibisono ${ }^{1)}$, Susanti ${ }^{1)}$ \\ 1) Program Studi Budidaya Perkebunan, STIPER Agrobisnis Perkebunan (STIP-AP), Jl Williem \\ Iskandar/Pancing, Medan. 20222, 2) Fakultas Pertanian, Universitas Al Wasliyah (UNIVA), Jl. \\ Sisingamangaraja KM. 5,5 No. 10 Harjosari I, Medan, 20147 \\ E-mail: sakiah@stipap.ac.id
}

\begin{abstract}
Palm oil fronds is one of the wastes originating from the oil palm industry which are difficult to decompose. The right decomposer application is one of the success keys, if the oil palm fronds are processed into compost hence the expected quality of compost is achieved. This research aim was to determine the quality of oil palm fronds compost with Trichoderma harzianum and cow dung application based on $N, P, K$ nutrients content, $C$ organic and C/N compost ratio. The research design used was factorial complete randomized design, the first factor was cow dung $(0 \mathrm{~kg}, 1 \mathrm{~kg}$, and $2 \mathrm{~kg})$ and the second factor was Trichoderma harzianum $(0 \mathrm{~g}, 50 \mathrm{~g}$, and $100 \mathrm{~g})$. Research observations included compost temperature, compost $\mathrm{pH}, \mathrm{N}, \mathrm{P}, \mathrm{K}, \mathrm{C}$-organic, and $\mathrm{C} / \mathrm{N}$ compost ratios. The results showed that the application of cow dung, Trichoderma harzianum and their interactions had no significant effect on $N, P, K$ nutrient content, C-organic, and $C / N$ compost ratios, as a whole, the observed compost characteristics met compost criteria based on SNI 7030-200.
\end{abstract}

Keywords: compost, national standard, quality

DOI: http://dx.doi.org/ 10.25181/jaip.v7i2.1118

Diterima: 23 April 2019 / Disetujui: 12 September 2019 / Diterbitkan: 15 Oktober 2019

\section{PENDAHULUAN}

Kelapa sawit merupakan salah satu komoditas perkebunan primadona masyarakat Indonesia, hal ini ditunjukkan dengan semakin luasnya perkebunan kelapa sawit nasional. Berdasarkan data Direktorat Jenderal Perkebunan, luas lahan perkebunan kelapa sawit di Indonesia pada tahun 2017 mencapai 12,3 juta hektar dan produksi tandan buah segar (TBS) 35,3 juta ton. Meningkatnya luas lahan perkebunan kelapa sawit diiringi dengan meningkatnya volume limbah yang dihasilkan, salah satunya yaitu pelepah yang bersumber dari hasil pruning (penunasan) tanaman kelapa sawit. 
Penunasan merupakan upaya untuk mengatur jumlah pelepah yang perlu dipertahankan atau yang tinggal di pohon. Penunasan bertujuan untuk menjaga keseimbangan fisiologis tanaman dan sanitasi, memperlancar penyerbukan, memudahkan panen dan pengamatan matang panen, menghindari tersangkutnya brondolan di ketiak pelepah, dan mempermudah pembersihan piringan dan pemupukan (Sutarta et al., 2003).

Tanaman kelapa sawit mengeluarkan 18-30 pelepah setiap tahunnya, dimana 8-22 pelepah diantaranya terdapat buah dan lainnya tidak menghasilkan buah. Rerata pelepah yang dipotong setiap panen kelapa sawit adalah 1-3 pelepah jadi setiap bulannya ada 2-4 pelepah yang harus dipotong dengan bobot 5,40 kg per pelepah (Darmosarkoro, 2012). Pelepah hasil penunasan dipotong menjadi 3 bagian, kemudian disusun di gawangan mati. Khusus pada areal bergelombangberbukit pelepah disusun searah dengan kontur atau tegak lurus dengan arah lereng. Penunasan pelepah dilaksanakan dengan rotasi 10-12 bulan sekali (Sutarta et al., 2003).

Adanya penumpukan pelepah di sela-sela tanaman kelapa sawit khususnya di gawangan mati beberapa perkebunan kelapa sawit berpotensi menjadi sarang/inang bagi hama dan penyakit seperti beberapa jenis hama ulat dan kumbang pemakan daun, tikus, bahkan ular. Jenis-jenis penyakit utama kelapa sawit disebabkan oleh Ganoderma, Pythium, dan Rhizoctonia (Risza, 2010).

Kandungan unsur hara pada pelepah kelapa sawit yaitu N 2,6-2,9 \%; P 0,16-0,19 \%; K 1,11,3\%; Ca 0,5-0,7 \%; Mg 0,3-0,45 \%; S 0,25-0,40 \%; Cl 0,5-0,7 \% (Syahfitri, 2008). Komponen penyusun terbesar pelepah kelapa sawit adalah holoselulosa 72,67 \%; alfaselulosa 36,74 \%; lignin $21,39 \%$ dan pentosan 22,19\% (Darmosarkoro, 2012).

Berbagai penelitian telah dilakukan dalam usaha memaksimalkan pemanfaatan pelepah kelapa sawit antara lain sebagai bahan baku pakan ternak (Rizali, Fachrianto, Ansari, \& Wahdi, 2018), bahan baku briket arang (Sarwono, Adinegoro, \& Widarti, 2018), bahan baku bioethanol (Rilek, Hidayat, \& Sugiarto, 2017), bahan dasar produk bergaya etnik (Andansari, Cahyadi, \& Marlang, 2013), dan bahan baku kompos (Yuniati, 2014) yang secara keseluruhan masih dalam proses penyempurnaan.

Pelepah kelapa sawit berpotensi besar untuk dijadikan sebagai bahan baku pupuk kompos, namun karena bahan penyusun pelepah kelapa sawit terdiri dari bahan yang sulit terdekomposisi maka dibutuhkan perlakuan khusus untuk mempercepat proses dekomposisi pelepah kelapa sawit. Kompos berbahan baku pelepah kelapa sawit yang dihasilkan Yuniati (2014) menunjukkan hasil analisa kompos, rata-rata C-organik 40-41 \%, kadar N 1,27-1,43\% dan rasio C/N 28,01-32,72. Berdasarkan SNI Kompos 19-7030-2004 bahwa nilai C-organik dan rasio C/N kompos belum sesuai kriteria SNI Kompos. Maka pada penelitian ini dilakukan pengomposan pelepah kelapa sawit menggunakan jamur Trichoderma harzianum serta kotoran sapi segar sebagai dekomposer.

Trichoderma harzianum merupakan cendawan yang mempunyai aktivitas antagonistik yang tinggi terhadap cendawan patogen tular tanah. T. harzianum dapat diisolasi dari berbagai macam tanah dan dari permukaan akar tanaman serta dari kayu busuk atau serasah (Suwahyono \& 
Wahyudi, 2004). Beberapa spesies Trichoderma telah dilaporkan sebagai agen hayati seperti $T$. harzianum, T. viridae dan T. koningii yang berspektrum luas pada tanaman pertanian. Biakan jamur Trichoderma diberikan ke areal pertanaman dan berlaku sebagai biodekomposer, serta dapat berlaku sebagai biofungisida yang berperan mengendalikan organisme patogen penyakit tanaman. Mengingat peran $T$. harzianum yang sangat besar dalam menjaga kesuburan tanah dan menekan populasi jamur patogen, T. harzianum memiliki potensi tinggi sebagai kompos aktif juga sebagai agen pengendali organisme patogen (Herlina \& Dewi, 2010).

Keunggulan dalam penggunaan jamur $T$. harzianum adalah selain jamur ini bisa menghasilkan enzim yang dapat memecah selulosa menjadi glukosa, jamur ini juga dapat digunakan sebagai biofungisida yang ramah lingkungan karena tidak menimbulkan pencemaran atau berdampak negatif pada lingkungan melainkan dapat mengembalikan keseimbangan alamiah dan kesuburan tanah (Soesanto, 2004).

Agar penguraian pelepah kelapa sawit dapat efektif, maka dalam penelitian ini kotoran sapi segar diberikan sebagai sumber mikroba lainnya. Kotoran sapi mengandung mikroba yang berperan dalam dekomposisi hingga dapat menjadi kompos. Mikroba tersebut yaitu mikroba lignolitik, mikroba selulolitik, mikroba proteolitik, mikroba lipolitik, mikroba aminolitik, dan mikroba fiksasi nitrogen (Sriatun, Hartutik, \& Taslimah, 2009). Mikroba lignolitik yang terkandung dalam kotoran sapi berfungsi untuk memecah ikatan lignin menjadi senyawa yang lebih sederhana sehingga dekomposisi bahan organik menjadi lebih cepat (Setiawan, 2010).

Penelitian ini bertujuan untuk menguji mutu kompos pelepah kelapa sawit dengan pemberian T. harzianum dan kotoran sapi ditinjau dari kadar C-organik, kadar N, kadar P, kadar K, dan rasio $\mathrm{C} / \mathrm{N}$ kompos.

\section{METODE PENELITIAN}

Penelitian berlangsung sejak April 2018 hingga Agustus 2018, pengomposan dilaksanakan di rumah kaca STIPER-Agrobisnis Perkebunan, dan pengujian sampel dilakukan di laboratorium Riset dan Teknologi Universitas Sumatera Utara. Penelitian menggunakan Rancangan Acak Lengkap Faktorial. Faktor pertama adalah kotoran sapi (S) terdiri dari 3 taraf yaitu $\mathrm{S}_{0}=$ tanpa kotoran sapi, $\mathrm{S}_{1}=$ kotoran sapi $1 \mathrm{~kg}$ dan $\mathrm{S}_{2}=$ kotoran sapi $2 \mathrm{~kg}$. Faktor kedua yaitu Trichoderma harzianum $(\mathrm{T})$ terdiri atas 3 taraf yaitu $\mathrm{T}_{0}=$ tanpa Trichoderma harzianum, $\mathrm{T}_{1}=$ Trichoderma harzianum $50 \mathrm{~g}$, dan $\mathrm{T}_{2}=$ Trichoderma harzianum $100 \mathrm{~g}$. Setiap kombinasi perlakuan diulang tiga kali sehingga diperoleh 27 satuan percobaan. Untuk mengetahui pengaruh perlakuan digunakan uji F pada taraf $5 \%$. Apabila terdapat pengaruh nyata terhadap parameter yang diamati, maka setiap perlakuan dibandingkan dengan menggunakan uji Beda Nyata Jujur (BNJ) pada taraf 5\%. 
Bahan yang digunakan adalah pelepah kelapa sawit yang berasal dari kebun praktek STIPAP Medan. Jamur T. harzianum berasal dari Balai Proteksi Tanaman Hortikultura Sumatera Utara, kotoran sapi berasal dari Dusun 1 Tambak, Pasar 1 Rejo, Kec. Percut Sei Tuan. Alat yang digunakan yaitu timbangan, mesin pencacah, ember, thermometer, $\mathrm{pH}$ meter, spektrometer, buret dan alat-alat laboratorium pendukung lainnya.

Adapun proses pengomposan yang dilakukan yaitu pelepah kelapa sawit dari bagian rachis (batang tempat munculnya daun) dan leaflets (daun) yang masih segar dicincang dengan ukuran 1$2 \mathrm{~cm}$ menggunakan mesin pencacah. Pelepah yang digunakan untuk satu perlakuan $4 \mathrm{~kg}$, secara keseluruhan dibutuhkan 14 pelepah. Selanjutnya dilakukan pengaplikasian jamur T. harzianum dan kotoran sapi sesuai dengan perlakuan. Jamur T. harzianum yang digunakan adalah yang dibiakkan pada media jagung dengan masa inkubasi 7 hari, kerapatan T. harzianum $10^{6}$. Aplikasi dekomposer dilakukan dengan mencampur terlebih dahulu $T$. harzianum dengan kotoran sapi dan diinkubasi selama 2 hari, kemudian dicampurkan dengan pelepah kelapa sawit yang telah dicacah dan dimasukkan ke dalam ember pengomposan. Bahan kompos yang telah dicampur diberi air untuk melembabkan bahan. Pembalikan kompos dilakukan 1x seminggu, pengomposan berlangsung selama 8 minggu.

Pengamatan terhadap suhu dan kelembaban kompos dilakukan satu kali seminggu. Suhu kompos diukur dengan termometer dan kelembaban kompos diukur dengan cara meremas kompos. Jika ada air yang menetes dari kompos menandakan bahwa kadar air kompos berlebih, tapi jika kompos terlalu kering maka ditambahkan air hingga kondisi kompos lembab.

Pemanenan kompos dilakukan setelah 8 minggu pengomposan dengan kriteria kompos berwarna coklat kehitaman, remah, dan tidak berbau. Selanjutnya diambil sampel kompos dari setiap perlakuan dan ulangan. Kompos diambil dari bagian atas, tengah dan bawah lalu dijadikan satu.

Pengamatan yang dilakukan pada penelitian ini yaitu suhu kompos diamati setiap minggu selama 8 minggu menggunakan termometer, $\mathrm{pH}$ diamati setiap minggu selama 8 minggu menggunakan $\mathrm{pH}$ meter pocket, C-Organik dianalisis dilaboratorium menggunakan metode Walkley and Black, kadar $\mathrm{N}$ dianalisis dengan metode Kjeldahl, $\mathrm{P}$ dianalisis dengan metode Spectrofotometry, dan K dianalisis dengan metode Flamefotometry. Rasio C/N merupakan hasil pembagian kadar C-organik dengan kadar $\mathrm{N}$.

\section{HASIL DAN PEMBAHASAN}

\section{Suhu kompos}

Suhu kompos selama 8 minggu pengomposan disajikan pada Tabel 1. Selama proses pengomposan suhu rata-rata pada minggu pertama hingga minggu kedelapan antara $33^{\circ} \mathrm{C}$ hingga $36^{\circ} \mathrm{C}$. Suhu pada pengomposan tidak mencapai fase termofilik $\left(45^{\circ} \mathrm{C}-65^{\circ} \mathrm{C}\right)$, hal ini disebabkan 
tumpukan kompos tidak mencapai tinggi tumpukan kompos yang optimum yaitu 1-2,2 m. Suhu diawal pengomposan $35^{\circ} \mathrm{C}$ dan pada akhir pengomposan $33^{\circ} \mathrm{C}$, ini menunjukkan adanya aktivitas mikroba dalam mendekomposisi bahan organik sehingga menghasilkan energi dalam bentuk panas, $\mathrm{CO}_{2}$ dan uap air (Asyeerem, 2012).

Selama proses pengomposan dilakukan pengadukan seminggu sekali pada setiap perlakuan dengan tujuan untuk meningkatkan aerasi. Pembalikan timbunan kompos membantu pencampuran dan pelonggaran serta aerasi timbunan, dan menurunkan secara perlahan hingga stabil (Sutanto, 2002). Stabilnya suhu diduga karena seluruh tumpukan kompos sudah mengalami fase pendinginan dan kematangan yang ditandai dengan turunnya temperatur dari temperatur puncak menuju kestabilan (Indrawaty, 2017).

Tabel 1. Rataan suhu kompos pelepah kelapa sawit dengan pemberian kotoran sapi dan T. harzianum

\begin{tabular}{|c|c|c|c|c|c|c|c|c|c|}
\hline \multirow[b]{2}{*}{ Perlakuan } & \multicolumn{8}{|c|}{ Suhu $\left.{ }^{\left({ }^{\circ}\right.} \mathrm{C}\right)$} & \multirow[b]{2}{*}{ Rataan } \\
\hline & $\begin{array}{c}1 \\
\text { MSP }\end{array}$ & $\begin{array}{c}2 \\
\text { MSP } \\
\end{array}$ & $\begin{array}{c}3 \\
\text { MSP } \\
\end{array}$ & $\begin{array}{c}4 \\
\text { MSP } \\
\end{array}$ & $\begin{array}{c}5 \\
\text { MSP } \\
\end{array}$ & $\begin{array}{c}6 \\
\text { MSP } \\
\end{array}$ & $\begin{array}{c}7 \\
\text { MSP } \\
\end{array}$ & $\begin{array}{c}8 \\
\text { MSP } \\
\end{array}$ & \\
\hline $\mathrm{S}_{0}$ (kontrol) & 35 & 35 & 35 & 35 & 35 & 35 & 33 & 34 & 35 \\
\hline $\mathrm{S}_{1}($ kotoran sapi $1 \mathrm{~kg})$ & 35 & 35 & 35 & 35 & 35 & 35 & 32 & 34 & 35 \\
\hline $\mathrm{S}_{2}$ (kotoran sapi $2 \mathrm{~kg}$ ) & 36 & 36 & 36 & 36 & 36 & 36 & 33 & 35 & 36 \\
\hline $\mathrm{T}_{0}$ (kontrol) & 35 & 35 & 37 & 35 & 37 & 36 & 33 & 31 & 35 \\
\hline $\mathrm{T}_{1}($ T.harzianum $50 \mathrm{~g})$ & 36 & 35 & 38 & 35 & 37 & 36 & 33 & 31 & 35 \\
\hline $\mathrm{T}_{2}($ T.harzianum $100 \mathrm{~g})$ & 35 & 35 & 37 & 36 & 37 & 36 & 33 & 32 & 35 \\
\hline Rataan & 35 & 35 & 36 & 35 & 36 & 36 & 33 & 33 & \\
\hline
\end{tabular}

Keterangan: MSP = minggu setelah pengomposan

\section{Nilai pH kompos}

Rataan $\mathrm{pH}$ kompos pelepah kelapa sawit dengan pemberian kotoran sapi dan T. harzianum selama 8 minggu terdapat pada Tabel 2. Rataan pH kompos pada minggu ke-1 dan ke-2 berkisar 8,2-8,3 selanjutnya menurun pada setiap minggunya. Kenaikan $\mathrm{pH}$ dapat disebabkan karena adanya aktivitas mikroorganisme yang menguraikan bahan organik. Nilai $\mathrm{pH}$ kompos yang naik menunjukkan bahwa adanya amonia dan aktivitas mikroba yang mempengaruhi kenaikan $\mathrm{pH}$ kompos (Komarayati, Mustaghfirin, Sofyan, 2018). Pada minggu ke-3 sampai dengan minggu ke-8, rataan $\mathrm{pH}$ kompos menurun hingga berkisar 7,3-7,8. Penurunan $\mathrm{pH}$ kompos dikarenakan terjadinya proses perombakan bahan organik dan menghasilkan senyawa asam sehingga menyebabkan $\mathrm{pH}$ menurun (Pulungan, Lubis, Zahara, \& Fairuzah, 2017). 
Tabel 2. Rataan $\mathrm{pH}$ kompos pelepah kelapa sawit dengan pemberian T. harzianum dan kotoran sapi

\begin{tabular}{|c|c|c|c|c|c|c|c|c|c|}
\hline \multirow[b]{2}{*}{ Perlakuan } & \multicolumn{8}{|c|}{$\mathrm{pH}$} & \multirow[b]{2}{*}{ Rataan } \\
\hline & $\begin{array}{c}1 \\
\text { MSP }\end{array}$ & $\begin{array}{c}2 \\
\text { MSP }\end{array}$ & $\begin{array}{c}3 \\
\text { MSP }\end{array}$ & $\begin{array}{c}4 \\
\text { MSP }\end{array}$ & $\begin{array}{c}5 \\
\text { MSP }\end{array}$ & $\begin{array}{c}6 \\
\text { MSP }\end{array}$ & $\begin{array}{c}7 \\
\text { MSP }\end{array}$ & $\begin{array}{c}8 \\
\text { MSP }\end{array}$ & \\
\hline $\mathrm{S}_{0}$ (kontrol) & 8,3 & 8,2 & 7,3 & 7,5 & 7,5 & 7,5 & 7,4 & 7,7 & 7,7 \\
\hline $\mathrm{S}_{1}$ (kotoran sapi $1 \mathrm{~kg}$ ) & 8,3 & 8,2 & 7,3 & 7,6 & 7,7 & 7,6 & 7,5 & 7,8 & 7,8 \\
\hline $\mathrm{S}_{2}$ (kotoran sapi $2 \mathrm{~kg}$ ) & 8,2 & 8,1 & 7,2 & 7,6 & 7,7 & 7,6 & 7,5 & 7,8 & 7,7 \\
\hline $\mathrm{T}_{0}$ (kontrol) & 8,4 & 8,2 & 7,2 & 7,5 & 7,7 & 7,6 & 7,5 & 7,7 & 7,7 \\
\hline $\mathrm{T}_{1}($ T. harzianum $50 \mathrm{~g})$ & 8,2 & 8,2 & 7,3 & 7,6 & 7,5 & 7,6 & 7,5 & 7,8 & 7,7 \\
\hline $\mathrm{T}_{2}($ T. harzianum $100 \mathrm{~g})$ & 8,3 & 8,1 & 7,3 & 7,5 & 7,6 & 7,6 & 7,5 & 7,7 & 7,7 \\
\hline Rataan & 8,3 & 8,2 & 7,3 & 7,6 & 7,6 & 7,6 & 7,5 & 7,8 & \\
\hline
\end{tabular}

Keterangan: $\mathrm{MSP}=$ minggu setelah pengomposan

\section{Kadar C-Organik, kadar N, rasio C/N, kadar P, dan K kompos}

Hasil analisis sidik ragam menunjukkan bahwa pemberian kotoran sapi (S) dan Trichoderma harzianum (T) serta interaksi keduanya berpengaruh tidak nyata terhadap kadar Corganik, kadar N, kadar P, kadar K, dan rasio C/N kompos pelepah kelapa sawit. Rataan kadar Corganik, kadar N, kadar $\mathrm{P}$, kadar K, dan rasio $\mathrm{C} / \mathrm{N}$ kompos pelepah kelapa sawit dapat dilihat pada Tabel 3.

Tabel 3. Rataan kadar C-Organik, N, P, K dan rasio C/N kompos

\begin{tabular}{|c|c|c|c|c|c|}
\hline \multirow[t]{2}{*}{ Perlakuan } & C-organik & $\mathrm{N}$ & $\mathrm{P}$ & K & $\begin{array}{c}\text { rasio } \\
\mathrm{C} / \mathrm{N}\end{array}$ \\
\hline & $\%$ & $\%$ & $\%$ & $\%$ & \\
\hline $\mathrm{S}_{0}$ (kontrol) & 25,03 & 2,06 & 0,28 & 0,19 & 12,17 \\
\hline $\mathrm{S}_{1}($ kotoran sapi $1 \mathrm{~kg}$ ) & 22,60 & 1,95 & 0,28 & 0,18 & 11,65 \\
\hline $\mathrm{S}_{2}$ (kotoran sapi $2 \mathrm{~kg}$ ) & 22,04 & 1,88 & 0,31 & 0,19 & 11,79 \\
\hline $\mathrm{T}_{0}$ (kontrol) & 22,35 & 1,89 & 0,26 & 0,19 & 11,89 \\
\hline $\mathrm{T}_{1}(T$. harzianum $50 \mathrm{~g})$ & 23,68 & 1,97 & 0,31 & 0,18 & 12,04 \\
\hline $\mathrm{T}_{2}($ T. harzianum $100 \mathrm{~g})$ & 23,64 & 2,03 & 0,30 & 0,20 & 11,68 \\
\hline
\end{tabular}

Kadar C-organik, N, P, K dan rasio C/N kompos pelepah kelapa sawit berpengaruh tidak nyata pada semua perlakuan. Hal yang sama pada pembuatan kompos pelepah kelapa sawit menggunakan dekomposer MOL yang terbuat dari jeruk, mangga, nanas, dan pepaya menunjukkan hasil yang tidak berbeda nyata pada pengamatan rasio $\mathrm{C} / \mathrm{N}, \mathrm{pH}$ dan rendemen kompos (Surya \& Suyono, 2013). Demikian juga dengan pengomposan pelepah daun kelapa sawit menggunakan dekomposer indegenous (diambil dari tumpukan pelepah di lapangan, diperolah jenis Trichoderma asperellum), dekomposer komersil juga menunjukkan kadar $\mathrm{C}, \mathrm{N}, \mathrm{P}, \mathrm{K}$ rasio $\mathrm{C} / \mathrm{N}$, dan $\mathrm{pH}$ tidak 
berbeda nyata antar perlakuan (Yuniati, 2014). Pada proses pengomposan, karbon dibutuhkan oleh mikroba sebagai sumber energi untuk pertumbuhannya dan nitrogen untuk sintetis protein (Hidayati et al., 2011). Namun, kemampuan mikroba dekomposer dapat terhambat perkembangannya oleh sulitnya bahan kompos didekomposisi. Bahan utama kompos pada penelitian ini adalah pelepah kelapa sawit, yang mana penyusun pelepah kelapa sawit berasal dari bahan yang sulit terdekomposisi seperti holoselulosa, alfaselulosa, lignin dan pentosan (Darmosarkoro, 2012). Nilai rerata kadar komponen kimia pada pelepah sawit varietas tenera menurut bagiannya dari pangkal, tengah, ujung berturut-turut dengan rerata lignin 20,7\%, 18,95\%, $16,69 \%$, holoselulosa $81,57 \%, 80,33 \%, 79,24 \%$ dan alfaselulosa $44,57 \%, 43,56 \%, 43,26 \%$ (Arpinaini, Sumpono, \& Yahya, 2017).

Faktor yang membatasi pertumbuhan mikroba adalah kadar nitrogen dan bahan dasar kompos yang mempunyai rasio $\mathrm{C} / \mathrm{N}$ yang besar (Hidayati et al., 2011). Proses dekomposisi baik secara aerob maupun anaerob akan menghasilkan hara dan humus, proses bisa berlangsung jika tersedia N, P dan K. Penguraian berlangsung cepat apabila perbandingan antara kadar Corganik:N:P:K dalam bahan terurai setara 30:1:0,1:0,5 (Gaur, 1980).

\section{Standar Kualitas Kompos}

Mengacu pada standar kualitas kompos berdasarkan SNI 19-7030-2004, kadar C-organik, N, P, K, dan rasio C/N kompos dapat dilihat pada Tabel 4.

Tabel 4. Kulitas kompos pelepah kelapa sawit berdasarkan SNI 19-7030-2004

\begin{tabular}{llcccc}
\hline \multirow{2}{*}{ No. } & \multirow{2}{*}{ Parameter } & \multicolumn{2}{c}{ SNI 19-7030-2004 } & \multirow{2}{*}{ Hasil pengamatan } & \multirow{2}{*}{ Keterangan } \\
\cline { 3 - 4 } & & Minimum & Maksimum & & \\
\hline 1 & C-organik & $9,80 \%$ & $32 \%$ & $22 \%-25 \%$ & Memenuhi standar \\
2 & Nitrogen & $0,40 \%$ & - & $1,88 \%-2,06 \%$ & Memenuhi standar \\
3 & Fosfor & $0,10 \%$ & - & $0,26 \%-0,31 \%$ & Memenuhi standar \\
4 & Kalium & $0,20 \%$ & - & $0,18 \%-0,20 \%$ & Memenuhi standar \\
5 & Rasio C/N & - & 20 & $11,65-12,17$ & Memenuhi standar \\
\hline
\end{tabular}

Berdasarkan SNI 19-7030-2004, kompos yang dihasilkan pada penelitian ini memenuhi standar kualitas kompos ditinjau dari kadar C-organik, N, P, K serta rasio C/N kompos. Kompos merupakan salah satu pupuk organik yang memiliki fungsi kimia yang penting seperti penyedia unsur hara makro dan mikro meskipun jumlahnya relatif sedikit, meningkatkan kapasitas tukar kation (KTK) tanah dan dapat membentuk senyawa kompleks dengan ion logam yang meracuni tanaman seperti Al, Fe dan Mn (Hidayati et al., 2011). Mikroba aktif yang terdapat dalam kompos juga dapat berperan dalam meningkatkan ketersediaan unsur hara. Unsur hara makro pada pupuk kandang yang ditambahkan dalam proses pengomposan, diduga hanya sebagian saja yang dipergunakan oleh bakteri pengurai. Sisa unsur makro yang tidak dimanfaatkan oleh bakteri tetap bercampur pada kompos, yang selanjutnya berfungsi sebagai penambah unsur hara dalam kompos 
yang dihasilkan (Yuniati, 2014). Selain itu, Trichoderma sp. yang juga dimanfaatkan sebagai dekomposer dapat membentuk simbiosis mutualisme dengan tanaman karena kemampuan strain Trichoderma untuk berkembang biak dan fungsinya dalam mengontrol patogen akar (Harman, Howell, Viterbo, Chet, \& Lorito, 2004).

\section{KESIMPULAN}

Pemberian kotoran sapi dan Trichoderma harzianum pada pengomposan pelepah kelapa sawit berpengaruh tidak nyata terhadap kadar $\mathrm{C}$-organik, N, P, K dan rasio $\mathrm{C} / \mathrm{N}$ kompos. Bahan dasar kompos sangat mempengaruhi hasil pengomposan. Mengacu pada SNI 19-7030-2004, kadar C-organik, N, P, K, dan rasio C/N kompos yang dihasilkan telah memenuhi standar mutu kompos.

\section{DAFTAR PUSTAKA}

Andansari, D., Cahyadi, D. \& Marlang, H. A. (2013). Pemanfaatan limbah pelepah kelapa sawit untuk bahan dasar pembuatan produk fungsional bergaya etnik Dayak di Kalimantan Timur. Seminar Nasional Rekayasa Teknologi Industri dan Informasi (pp. 44-49). Sekolah Tinggi Teknologi Nasional.

Arpinaini, A., Sumpono, S., \& Yahya, R. (2017). Studi komponen kimia pelepah sawit varietas tenera dan pengembangannya sebagai modul pembelajaran kimia. PENDIPA Journal of Science Education, 1(1), 1-11.

Asyeerem, F. (2012). Pemanfaatan agen hayati Trichoderma dan bakteri pada pengomposan Ageratum conyzoides, Thitonia diversifolia Hemsley. A. Gray dan ampas tebu. Jurnal Agrotek $3(3), 15-24$.

Darmosarkoro, W. (2012). Integrasi Sawit Sapi dan Energi. Medan: Pusat Penelitian Kelapa Sawit.

Gaur, A. (1980). A manual of Rural Composting. Project Field Document No 15. United Nations: Food and Agriculture Organization.

Harman, G. E., Howell, C. R., Viterbo, A., Chet, I., \& Lorito, M. (2004). Trichoderma speciesopportunistic, avirulent plant symbionts. Nature reviews microbiology, 2(1), 43-56.

Sriatun, S., Hartutik, S., \& Taslimah, T. (2009). Pemanfaatan Limbah Penyulingan Bunga Kenanga sebagai Kompos dan Pengaruh Penambahan Zeolit terhadap Ketersediaan Nitrogen Tanah. Jurnal Kimia Sains dan Aplikasi, 12(1), 17-22.

Herlina, L. \& Dewi, P. (2010). Penggunaan kompos aktif trichiderma harzianum dalam meningkatkan pertumbuhan tanaman cabai. Sains dan Teknologi, 11-17.

Hidayati, Y. A., Kurnani, T. B. A., Marlina, E. T., \& Harlia, E. (2011). Kualitas Pupuk Cair Hasil Pengolahan Feses Sapi Potong Menggunakan Saccharomyces cereviceae (Liquid Fertilizer Quality Produced by Beef Cattle Feces Fermentation Using Saccharomyces cereviceae). Jurnal Ilmu Ternak, 11(2), 104-107.

Indrawaty, V. (2017). Pengaruh Penggunaan Urin Sebagai Sumber Nitrogen Terhadap Bentuk Fisik dan Unsur Hara. Jambi: Universitas Jambi. 
Komarayati, S., Mustaghfirin, M., \& Sofyan, K. (2018). Kualitas Arang Kompos Limbah Industri Kertas dengan Variasi Penambahan Arang Serbuk Gergaji The qualities of Compost Charcoal Manufactured from Paper-mill Waste with Varying Addition of Charcoal Sawdust. Jurnal Ilmu dan Teknologi Kayu Tropis, 5(2), 78-84.

Pulungan, M. H., Lubis, L., Zahara, F., \& Fairuzah, Z. (2014). Uji efektifitas Trichoderma harzianum dengan formulasi granular ragi untuk mengendalikan penyakit jamur akar putih (Rigidoporus microporus (Swartz: Fr.) Van Ov) pada tanaman karet di pembibitan. Agroekoteknologi, 2(2), 497-512.

Rilek, N. M., Hidayat, N., \& Sugiarto, Y. (2017). Hidrolisis Lignoselulosa Hasil Pretreatment Pelepah Sawit (Elaeis guineensis Jacq) menggunakan $\mathrm{H} 2 \mathrm{SO} 4$ pada Produksi Bioetanol. Industria: Jurnal Teknologi dan Manajemen Agroindustri, 6(2), 76-82.

Risza, S. (2010). Masa depan perkebunan kelapa sawit Indonesia. Yogyakarta: Kanisius.

Surya, R. E., \& Suyono. (2013). Pengaruh pengomposan terhadap rasio C/N kotoran ayam dan kadar hara NPK tersedia serta kapasitas tukar kation tanah. Unesa Journal of Chemistry, 2(1), 137-144.

Rizali, A., Fachrianto, F., Ansari, M. H., \& Wahdi, A. (2018). pemanfaatan limbah pelepah dan daun kelapa sawit melalui fermentasi Trichoderma $s p$. sebagai pakan sapi potong. EnviroScienteae, 14(1), 1-7.

Samudro, G., Syafrudin, S., \& Sujiwo, B. (2012) Pemanfaatan lumpur aktif dan EM4 sebagai aktivator dalam proses pengomposan limbah kulit bawang dengan sludge. Jurnal Presipitasi: Media Komunikasi dan Pengembangan Teknik Lingkungan, 9(2), 51-63.

Sarwono, E., Adinegoro, M. B., \& Widarti, B. N. (2018). Pengaruh variasi komposisi batang, pelepah, dan daun tanaman kelapa sawit terhadap kualitas briket bioarang. Teknologi Lingkungan, 2(1), 11-22.

Setiawan, B. (2010). Membuat Pupuk Kandang Secara Cepat. Jakarta: Penebar Swadaya.

Soesanto, L. (2004). Ilmu Penyakit Pasca Panen. Universitas Jenderal Soedirman: Purwokerto.

Sutanto, R. (2002). Penerapan Pertanian Organik. Yogyakarta: Kanisius.

Sutarta, E. S., W. Darmosarkoro, D. Asmono, A. Susanto, S. Prawirosukarto., R. Y. Purba \& P. Purba. (2003). Pemeliharaan Tanaman Kelapa Sawit Menghasilkan. Dalam P. P. Sawit, Budidaya Kelapa Sawit (hal. 6-3;6-4). Medan: Pusat Penelitian Kelapa Sawit.

Suwahyono, U. \& Wahyudi, P. (2004). Penggunaan Biofungisida pada Usaha Perkebunan. Dipetik Agustus 2018, dari http://.iptek.net.id/ind/terapan/terapan_idx.php?doc=artikel_12

Syahfitri, M. M. (2008). Analisa Unsur Hara Fosfor (P) pada Daun Kelapa Sawit Secara Spektrofotometri di Pusat Penelitian Kelapa Sawit (PPKS) Medan.

Yuniati, S. (2014). Pengomposan Pelepah Daun Kelapa Sawit dengan Biodekomposer Berbeda serta Pemanfaatannya Sebagai Amelioran. Bogor: Institut Pertanian Bogor. 